Relations industrielles

Industrial Relations

\title{
Christel Lane, Management and Labour in Europe
}

\section{Roy J. Adams}

Volume 46, numéro 1, 1991

URI : https://id.erudit.org/iderudit/050659ar

DOI : https://doi.org/10.7202/050659ar

Aller au sommaire du numéro

Éditeur(s)

Département des relations industrielles de l'Université Laval

ISSN

0034-379X (imprimé)

1703-8138 (numérique)

Découvrir la revue

Citer ce compte rendu

Adams, R. J. (1991). Compte rendu de [Christel Lane, Management and Labour in Europe]. Relations industrielles / Industrial Relations, 46(1), 237-238.

https://doi.org/10.7202/050659ar

Tous droits réservés (C) Département des relations industrielles de l'Université Laval, 1991
Ce document est protégé par la loi sur le droit d'auteur. L’utilisation des services d'Érudit (y compris la reproduction) est assujettie à sa politique d'utilisation que vous pouvez consulter en ligne.

https://apropos.erudit.org/fr/usagers/politique-dutilisation/ 
Management and Labour in Europe, by Christel LANE, Brookfield, VT, Gower Publishing Company, 1989, 328 p., ISBN 1-85278-058-4 et ISBN 1-85278-208-0 (pbk).

One of the most difficult types of social analysis requires the researcher systematically and simultaneously to compare social institutions and practices across countries. In comparative industrial relations the student will typically be concerned with interesting aspects of a given country such as co-determination in West Germany, enterprise unionism in Japan, voluntarism in Britain and interest arbitration in Australia. Only infrequently is an effort made systematically to compare participation mechanisms, forms of unions, labour policy and dispute resolution techniques across several nations systematically. In this book Christel Lane, a sociologist who teaches at the University of Aston Business School, does a superb job of comparing various aspects of business management, human resources management and labour relations in Britain, France and West Germany.

Among the subjects covered are: work structuring, business governance, education and training including management development, management style and control techniques, performance reward structures, job design from Taylorism through work humanizing to flexible specialization, labour relations, industrial democracy and employment policy including a discussion of recent government efforts to make employment relations more flexible. There is also a fascinating chapter on industrial policy where the author reviews relations between business, government and the banks with regard to corporate policy and finance. In a typical chapter Lane first describes the situation in Britain, France and West Germany, based on a review not only of English but also of French and German language works as well as interviews she carried out in the three countries, and then she addresses the question of why the different patterns have emerged. She then speculates on the impact the differences have had on labour, management and society as a whole in the three countries.

Although I was already familiar with most of the "facts" reported by Lane, still I learned a good deal from her comprehensive and systematic analysis. For example, managements in France, Britain and Germany have all been attempting to introduce flexible specialization during the past decade but the Germans have been by far the most successful of the three. Why? Because the overall system of IR/HRM in Germany is far more compatible with flexibility than are the British and French systems. The large majority of Germany workers have received a broad vocational education and are able to accept responsibility for a wide range of tasks. Foremen are also highly qualified and the culture at the shop floor is professional and cooperative. In France, on the other hand, Taylorism has been triumphant. Jobs are narrow and hierarchies are tall. Both workers and foremen are undertrained and there is a great deal of animosity between labour and management. Therefore, cooperation at the shopfloor is not easy to achieve.

The British situation is similar to the French with a few notable exceptions. For example, British workers are better organized at the shop floor level and the unions often put up a more formidable barrier to management initiative. While lower level vocational education is poorly developed in both Britain and France, higher level technical education is prestigious and well developed in France where it first appeared in the 19th century in the Grandes Ecoles but much less so in the U.K.

In short the German system appears to be most consistent with the needs of the era, the French less so and the British the least and industrial performance in the three countries has pretty much followed this hierarchy in recent years. Not that IR/HRM should be expected to explain all of the economic differences between the three nations but it certainly forms part of the explanation. Lane also reviews attempts by French and British governments and managements to revise practice with a view towards the needs of the day with only limited success. 
What is wrong with this book? Not much really. I found the theoretical chapter, which reviewed three competing approaches to comparative analysis of business organization (contingency theory, political economy and what Lane calls the cultural/institutional approach) to be not very illuminating. I also felt that Lane's dogged adherence to her three country design was, in the final result, a bit too rigid. There is, for example, almost no discussion of the work humanizing movement in Scandinavia where it reached its highest level of development. Nor is there much discussion of Japanese practice and the impact of Japan on the current flexibility debate. As a result this book might be usefully assigned as part of a course on comparative IR/HRM, but it would have to be generously supplemented with additional materials.

The positive aspects of Management and Labour in Europe are many and its faults are few. I highly recommend it for anyone seriously interested in comparative IR and HRM.

Roy J. ADAMS

McMaster University

Change in Industrial Relations: The Organization and Environment, by P.B. BEAUMONT, London, Routledge, 1990, 347 p., ISBN 0-415-04344-1.

There has long been a tendency to look across the Atlantic and south of the border for solutions to Canadian problems or images of the future. In the broadly defined field of industrial relations this tendency has been particularly marked. Some have seen America's "free" labour market as the way to create jobs. Others have viewed with dismay declining employment in traditional manufacturing industries and reductions in union membership. Developments in the industrial relations system such as concession bargaining and employee involvement programmes have attracted attention. Recently, British managers and academics have begun to use the jargon of "human resource management" in an attempt to keep up with American fashion. So what has been happening in industrial relations? This book, drawing on insights from economics, organizational behaviour, and urban and regional research, as well as from the traditional industrial relations literature, aims to provide some of the answers. Its well-known author claims not only to describe and interpret recent developments but also to raise the question of where industrial relations is going in the future.

Focusing on collective bargaining, the author examines changes in the British system of industrial relations in the $1980 \mathrm{~s}$, and places them in a wider context by frequent reference to developments in the USA. The 1980 s witnessed a wide range of changes in industrial relations in Britain, such as the growth of non-union firms, trade union decline, the emergence of human resource management practices, and an increase in labour-management co-operation. As a result, there is increased controversy about its future development. Although the book is not explicitly based on a comparative or cross-national framework of analysis, the approach adopted has been influenced by Kochan's American-based book, Collective Bargaining and Industrial Relations (1980). The essence of the conceptual approach adopted is that certain independent variables (notably the external environment, the bargaining characteristics of management, the organizational characteristics of unions, and bargaining structure) impact on certain dependent variables associated with collective bargaining. Namely the negotiations process, bargaining outcomes, contract administration and the union-management change process which, in turn, feed through to shape the goal attainment of the parties. The approach adopted here, however, differs from that of Kochan in treating industrial relations somewhat less of a discrete, self-contained entity, both in the individual-organization and wider-society settings. 